\title{
Immunohistochemical localization of fibronectin as a tool for the age determination of human skin wounds*
}

\author{
P. Betz ${ }^{1}$, A. Nerlich ${ }^{2}$, J.Wilske ${ }^{1}$, J. Tübel ${ }^{1}$, I. Wiest ${ }^{2}$, R.Penning ${ }^{1}$, and W. Eisenmenger ${ }^{1}$ \\ ${ }^{1}$ Department of Legal Medicine and ${ }^{2}$ Department of Pathology, University of Munich, Frauenlobstrasse 7a, W-8000 München 2 , \\ Federal Republic of Germany
}

Received October 14, 1991 / Received in revised form December 27, 1991

\begin{abstract}
Summary: We analyzed the distribution of fibronectin in routinely embedded tissue specimens from 53 skin wounds and 6 postmortem wounds. In postmortem wounds a faint but focal positive staining was exclusively found at the margin of the specimens which dit not extend into the adjacent stroma. Vital wounds were classified into 3 groups. The first comprising lesions with wound ages ranging from a few seconds to $30 \mathrm{~min}$, the second comprising those with wound ages upt to 3 weeks, and the third group with lesions more than 3 weeks old. Ten out of 17 lesions with a wound age up to $30 \mathrm{~min}$ showed a clear positive reaction within the wound area. Three specimens in this group were completely negative, while in 4 additional cases the result was not significantly different from postmortem lesions. These 7 cases were characterized by acute death with extremely short survival times (only seconds). In wounds up to 3 weeks old fibronectin formed a distinct network containing an increasing number of inflammatory cells corresponding to the wound age. In 2 cases with a survival time of 17 days and in all wounds older than 3 weeks fibronectin was restricted to the surface of fibroblasts and to parallel arranged fibers in the granulation tissue without any network structures. We present evidence that fibronectin is a useful marker for vital wounds with a survival time of more than a few minutes. Fibronectin appears before neutrophilic granulocytes migrate into the wound area. Since a faint positive fibronectin staining is seen in postmortem lesions and bleedings, we propose that only those wounds which show strong positive fibronectin staining also extending into the adjacent stroma should be regarded as vital.
\end{abstract}

Key words: Fibronectin - Immunohistochemistry Wound age

Zusammenfassung. Es wurden 53 vitale Hautwunden mit einem Wundalter von wenigen Sekunden/Minuten

\footnotetext{
* This study was supported by a grant from the "Deutsche Forschungsgemeinschaft" (grant Ei 209/3-1) and by a grant from the "Friedrich-Baur-Stiftung" University of Munich

Correspondence to: P. Betz
}

bis zu 6 Wochen sowie 6 postmortale Hautwunden und postmortale subcutane Blutungen immunhistochemisch untersucht. In einigen postmortal gesetzten Hautveränderungen war eine „positive“ Fibronektin-Reaktion nur in Randbereichen der Schnitte, hier jedoch stellenweise auch außerhalb des Läsionsgebietes feststellbar, wobei die Reaktion vornehmlich eine band- bis fleckförmige Ausprägung aufwies. In postmortal induzierten Blutungen waren stellenweise auch einzelne strangförmige Strukturen positiv anfärbbar, es zeigten sich hier jedoch keine scharf konturierten, kräftig anfärbbaren FibronektinStränge, wie sie bei vitalen Hautwunden bzw. Blutungen typischerweise auftraten, sondern eher verwaschene, teilweise auch körnig konfigurierte Reaktionsprodukte. In 10 von 17 vitalen Wunden mit einem Wundalter bis $\mathrm{zu} 30$ Minuten war eine eindeutig positive Reaktion im Wundbereich feststellbar. 3 Hautwunden zeigten im Wundgebiet keinerlei positive Anfärbung, in weiteren 4 Fällen war eine eindeutige Beurteilung unter Berücksichtigung der an postmortal induzierten Verletzungen erhobenen Befunde nicht möglich. Diese 7 Fälle waren sämtlich durch äußerst kurze Überlebenszeiten (wenige Sekunden?) charakterisiert. In älteren Hautwunden mit einem Wundalter von bis zu 3 Wochen war im Wundgebiet ein typisches, aus scharf konturierten und kräftig anfärbbaren Fibronektin-Strängen bestehendes Netzwerk nachweisbar, in welchem zahlreiche Entzündungszellen beobachtet werden konnten. Zwei Fälle mit einer Überlebenszeit von 17 Tagen sowie alle Hautwunden mit einem Wundalter über 3 Wochen zeigten nur noch umschriebene Fibronektin-Stränge zwischen kollagenen Fasern sowie eine positive Reaktion an der Oberfläche von Fibroblasten im Granulationsgewebe. Netzwerkartige, positiv reagierende Fibronektin-Strukturen waren in diesen Fällen nicht mehr abgrenzbar. Die Ergebnisse zeigen, $\mathrm{da}$ a die immunhistochemische Darstellung von Fibronektin zur Vitalitätsbeurteilung von Hautverletzungen mit einer Überlebenszeit von wenigen Minuten herangezogen werden kann. Unter Berücksichtigung der an postmortal gesetzten Hautveränderungen erhobenen Befunde sind jedoch nur solche Wunden als vital einzustufen, bei denen eine entsprechende Reaktion nicht nur am Wundrand und/oder in Blutungsbezirken auftritt, 
sondern auch in tiefer gelegen Abschnitten der Präparate nachgewiesen werden kann.

Schlïsselwörter: Fibronektin - Immunhistochemie Wundalter

\section{Introduction}

The age of lesions, especially of skin wounds, is usually estimated by analysis of cellular reactions, of altered enzyme activities as demonstrated by histochemical staining and by biochemical methods determining the concentration of substances such as histamine and serotonin in the wound area. Recently, monoclonal and polyclonal antibodies have been developed which can be used to specifically localize different proteins in various pathology situations.

The process of wound healing can be divided into an early exsudative phase followed by inflammatory reactions leading finally to a fibro-proliferative process. The extracellular matrix plays an important role in the tissue arrangement, especially in the late inflammatory and the fibro-proliferative phases. This concept is supported by the results of Eisenmenger et al. [10] which showed an age-dependent appearance of different collagens in skin lesions.

Fibronectin is an ubiquitous glycoprotein of the extracellular matrix which plays an important role as a mediator of cell-matrix-interactions [15, 21, 35]. Apart from the fibrillar form, fibronectin is detectable in plasma (cold insoluble globulin) [23]. Fibronectin is also a potent chemo-attractant mainly involved in tissue repair processes such as wound healing. Only a few studies exist where the distribution of fibronectin in wound tissue has been investigated. These results, however, indicate a vital function of this glycoprotein in the initial phase of wound healing [20].

This study was performed to analyze immunohistochemically the time-dependent appearance of fibronectin in wounds and to elucidate its possible advantage for the estimation of wound age.

\section{Material and methods}

A total of 53 skin lesions (surgical wounds, lacerations, stab wounds, hematomas and abrasions) with wound ages ranging from a few seconds to 6 weeks were analyzed. All tissue samples were obtained within 3 days after death. The age of the individuals ranged between 15 and 92 years old (mean 54 years). Furthermore postmortem lacerations were made on 6 corpses. Postmortem lesions caused by inguinal manipulations for the removal of blood samples were also tested.

From each wound 3 specimens were fixed in $4 \%$ PBS-formaldehyde and embedded in paraffin for the preparation of $2-3 \mu \mathrm{m}$ sections. These were enzymatically pretreated $(0,4 \%$ pepsin) and incubated with a polyclonal antibody against human fibronectin (Fa. Dako, Hamburg, FRG) using the technique previously reported [24]. The antigen was visualized by the ABC-method [16]. Undamaged skin specimens and immunohistochemical tests without the inclusion of the primary antibody were evaluated as controls.
The vital lesions were divided into 3 groups, the first comprising lesions with short survival times (up to $30 \mathrm{~min} ; n=17$ ), especially from victims of train or car accidents and from homicide victims. Group II included 28 wounds (survival time more than 30 min up to 3 weeks) and the other cases $(n=8)$ with a wound age up to 6 weeks old were classified as group III.

\section{Results}

\section{Normal skin}

In normal undamaged skin the endothelium basement membrane of larger blood vessels, epidermis and skin appendages showed a distinct, strong positive reaction. In the corium there was a rather homogenous weak and diffuse staining. Around fat cells of the subcutaneous layer no significant positive staining could be detected. All control experiments showed negative results.

\section{Postmortem lesions}

In postmortem specimens, a granular or spot-like and sometimes a band-shaped positive reaction was observed focally which was exclusively restricted to the margins (Fig. 1). In the deeper parts of the tissues, especially between the fat cells of the subcutis and between the fibers of the corium, no pronounced positive staining exceeding the normal weak staining in the skin corium could be observed. Some faded string-like positive structures could be seen at a few locations in the postmortem specimes (especially in bleedings). The typical scaffolding of ramifying fibronectin-fibers characterizing older vital wounds could not be detected.

\section{Vital wounds - Group I \\ (wound age from a few seconds up to $30 \mathrm{~min}$ )}

In this group 10 out of 17 cases showed a clear and distinct positive fibronectin reaction. In only 3 cases no positive staining at the wound margin could be detected. The remaining 4 cases could not be clearly classified since the staining pattern was similar to that of postmortem wounds. The specimens with no distinct positive staining were obtained from individuals with severe trauma $(2$ train accidents, 1 rupture of the aorta after a car accident, 3 car accidents and 1 homicide with severe cranio-cerebral trauma) indicating a survival time of only a few seconds. In the remaining 10 cases string-like ramifying and strongly reacting structures could be detected extending from the wound margin into the surrounding stroma (Fig. 2). A definite, and in 1 case a questionable cellular reaction with migration of neutrophilic granulocytes could be seen in only 2 out of 17 cases.

\section{Vital wounds - group II}

(wound age more than 30 min up to 3 weeks)

All specimens in this group showed enhanced positive reaction and especially a typical network of positive 

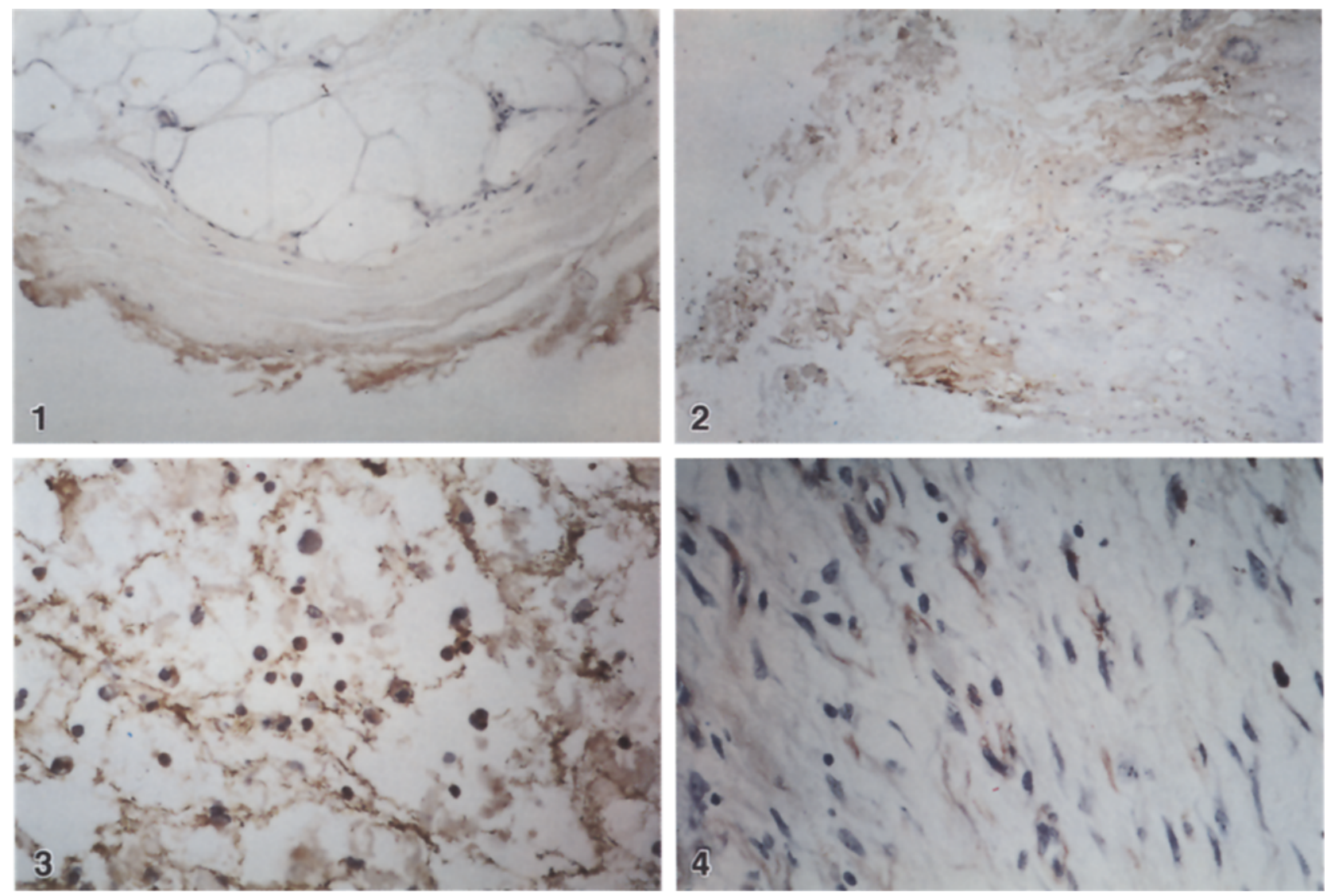

Fig. 1. Post mortem lesion:, band-shaped "positive" fibronectin reaction exclusively at the margin of the specimen, but not in deeper layers $(\mathrm{ABC}, 310 \times)$

Fig. 2. Vital skin wound (after severe cranio-cerebral trauma due to homicide; survival time of a few minutes): positive fibronectin staining at the margin but also in deeper layers of the wound area $(\mathrm{ABC}, 190 \times)$

Fig. 3. Vital skin wound (survival time of 2 days): typical fibronectin network with numerous inflammatory cells $(A B C, 310 \times)$

Fig.4. Granulation tissue (survival time of 17 days): positively staining fibronectin strands between connective tissue fibers; fibronectin reactivity present on the surface of fibroblasts ( $A B C$, $310 \times$ )

fibronectin strings containing numerous inflammatory cells within the wound area (Fig. 3). These structures could be seen in varying degrees at the wound margin and in hematomas as well as in deeper parts between the fibers of the corium and in the subcutis. In 2 cases an extensive granulation tissue (survival time 17 days) showed distinct strings of fibronectin associated with connective tissue fibers and the surface of fibroblasts.

Vital wounds - group III

(wound age ranging from 3 to 6 weeks)

These specimens were characterized by extensive granulation tissue. Here, a fibronectin pattern could be seen as previously described for the 2 cases in group II (Fig. 4).
With the exception of the normally reacting structures no positive staining could be observed and especially no fibronectin network. The endothelium of infiltrating capillaries also showed a distinct positive staining. In one 28day-old abrasion the basement membrane of the epidermal layer also stained intensively showing extensive granulation tissue.

In our series, we found no significant differences in the appearance of fibronectin depending on wound localization, wound type or age of the individuals.

\section{Discussion}

The analysis of extracellular matrix components for the determination of wound age has up till now only been performed by Eisenmenger et al. [10]. They demonstrated that the occurrence of various collagen types in human wounds was time dependent. The extracellular matrix component fibronectin has, however, not yet been analyzed in human wound tissue with respect to wound age.

Fibronectin is a glycoprotein of high molecular weight (450000 Dalton), existing in a soluble plasma form (concentration approximately $300 \mu \mathrm{g} / \mathrm{ml}$ ) and in a fibrillar form which is located in matrix fibers and associated with the surface of various cells [15]. Both forms have an identical molecular structure and are therefore antigenically identical [33]. Fibronectin is synthesized by fibroblasts [32] as well as endothelial cells [17] and hepatocytes [38]. Furthermore a synthesis by macrophages or monocytes [1] and astroglial cells [36] has been shown. 
In normal skin fibronectin typically occurs diffusely distributed in the connective tissue associated with collagen fibers, in the basement membranes of the endothelium, epidermal layer and skin appendages [21, 35]. Fibronectin is characterized by a high affinity to collagen, especially to collagen type III [19] and to fibrin [14] forming crosslinks under the influence of plasma-transglutaminase (activated factor XIII) [22, 23]. Furthermore, it enhances the attachment of fibroblasts [12] and endothelial cells [9] in cell culture. In particular, the high affinity to different extracellular matrix components such as collagen and fibrin mediates the attachment of cells to these substrates. Together with its chemo-attractive effect, fibronectin thus plays an important role in cell migration during wound healing $[8,15,28]$. Similarly, angiogenesis is enhanced during the development of granulation tissue [7]. Furthermore, Niewiarowski and co-workers [25] presumed an involvement of fibronectin in the contraction of wounds.

The intimate interaction between fibronectin and fibrin renders it feasible that this glycoprotein could be detected in early phases of wound healing $[13,31]$. On the other hand it is reasonable to assume that the fibronectin staining is reduced in the lesion area when cell migration into the wound area decreases [8].

To the best of our knowledge no comprehensive study exists which deals with the age-dependent appearance of fibronectin in human skin lesions. Only a few similar experimental investigations have been reported. Grinnell et al. [13] detected fibronectin in the fibrin clot with intense interaction to fibrin strings in skin wounds of guinea pigs with a wound age of $5 \mathrm{~h}$. They also found enhanced fibronectin formation between collagen fibrils of granulation tissue up to 18 days old. Clark and co-workers [7] investigated the role of fibronectin during neoangiogenesis in granulation tissue and reported a reduction of this glycoprotein in the capillary wall with decreasing capillary ingrowth. Repesh et al. [31] found fibronectin in the fibrin clot and described an intense reaction in 8-day-old granulation tissue from rabbits. Viljanto et al. [37] detected fibronectin at the margin of cellulose compresses in 3-hour-old surgical wounds. After $48 \mathrm{~h}$ the reaction in the interior parts of the compresses reached a maximum.

In 10 of the 17 cases with short survival times (up to $30 \mathrm{~min}$ ) we found a clear positive staining in the wound area. In 4 cases the positive reaction was not unambiguous and in only 3 further cases no staining at all was found in the wound area. These 7 cases were all characterized by an extremely short survival time. The remaining 10 cases showed a clear positive staining. These results indicate, that fibronectin can be detected only a few minutes after wounding. The positive reaction could not only be seen at the wound margin or in areas of bleeding, but also in deeper parts of the specimens between the fibers of the corium or in the subcutis. Therefore an "artefact" - as in our postmortem results - was excluded. Typical network structures of fibronectin strings appeared in the positively stained specimens.

In only 2 of the 17 cases investigated a distinct and in 1 case a questionable onset of cellular granulocytic immigration was observed, although an intense fibronectin staining was present. In general erythrocyte extravasation and cellular reaction with infiltration of inflammatory cells is assumed to be a sign of vitality $[4,27]$. Since, however, bleeding can be induced after death, this notion should be interpreted with care. Infiltration of neutrophilic granulocytes is widely regarded as an intrinsic vital reaction. There are, however, 2 difficulties: the earliest infiltrates do not occur before 10-30 min; with considerable variations between different observations [5, 27]. Lesions with earlier wounds could therefore not be classified as vital by this parameter. Secondly, since inflammatory cells may be "washed-in" artificially by bleeding, it is often not certain whether the granulocytes have indeed actively infiltrated the wound space.

Degranulation of mast cells in the wounded area has also been regarded as a sign of vitality. A massive degranulation in subcutaneous bleeding with a survival time of 2-4 h is described by Berg and Elbel [3], degranulation of single mast cells is assumed to appear much earlier. But the relevance of this observation for a classification of the lesions as vital, however, is of limited use due to practical reasons. In accordance with histological findings, Berg et al. [2] and Raekallio [30] found a significant increase of free histamine and serotonin in the wounded area when compared to normal skin even in wounds only a few minutes old. Furthermore, Raekallio [29] demonstrated an increase in the activities of beta-glucuronidase, monoamino-oxidase, unspecific esterases, and ATP-ase one hour after wounding using histochemistry. Jarecki and co-workers [18] described a shift of esterase-subtypes detected by electrophoresis in vital skin lesions.

Using immunohistochemistry, Oehmichen et al [26] observed an increase of the proteinase inhibitors alpha ${ }_{1}$ antitrypsin, alpha ${ }_{1}$-antichymotrypsin, and alpha $\mathrm{a}_{2}$-macroglobulin at the wound margin of skin lacerations within a survival time of 10 minutes. In postmortem wounds no positive reaction could be seen at the wound margin. However, since these proteins also occur in serum, a postmortem "wash-in effect" with increase at the wound margin may appear artificially.

As reported for proteinase inhibitors in skin lacerations, in our series fibronectin was detected even in wounds only a few minutes old and therefore apparently represents a considerably earlier vital marker than the immigration of neutrophilic granulocytes. In cases of very sudden death no positive reaction was expected which was in general confirmed by our results. In addition our extensive analysis provided evidence that postmortem wounds may contain certain fibronectin deposits. Fechner et al. [11] investigated the immunohistochemical localization of fibronectin and other proteins in mechanically damaged skeletal muscle and found - in contrast to our results - no postmortem reactivity. The postmortem fibronectin staining - detected in our series - however, can be morphologically distinguished from vital reactions. Thus, the weak reaction in postmortem lesions was restricted to the margin of the sections and did not extend into the stroma. In these instance the postmortem staining may be due to marginal drying artefacts. Similar reactions could also be observed at the margins of non-wounded skin specimens apparently due 
to "drying" processes. The positive, sometimes stringlike fibronectin staining in postmortem bleeding could be explained by the high affinity between this protein and fibrin and by postmortem blood clottings. In 1974 Schneider [34] investigated vital and postmortem fibrin clots by scanning electron microscopy and could not differentiate between them as had been previously proposed by Boehm and Tschomakov [6]. The fibronectin reactions in postmortem bleeding could therefore be due to postmortem fibrin clotting with attachment of fibronectin to fibrin filaments developing after death.

With regard to the postmortem fibronectin staining products the following aspects should be taken into consideration for the evaluation of fibronectin reaction in skin wounds: positive reaction products localized only at the margin and or in bleeding areas cannot be regarded as a vital sign. For the diagnosis of vitality it is therefore of great importance to detect positively stained fibronectin structures also in deeper parts of the specimens, especially the typical fibronectin network. Granular or spotlike reaction products as well as weak fibronectin filaments at the margins and or in areas of bleeding may simply indicate postmortem reactions. Special care should be taken for optimal preparation of tissue sections, since inadequate tissue preservation may result in false positive staining reactions. In our experience sharply contoured, strongly reacting fibronectin networks distant from the margin and from areas of bleeding can be defined as a vital sign.

The immunohistochemical detection of fibronectin in skin lesions is a useful sign for vitality in lesions with wound ages of only a few minutes.

After survival times of more than $30 \mathrm{~min}$ up to 3 weeks (group II; $n=28$ ) distinct network-like fibronectin-positive structures could be observed in every specimen containing enhanced amounts of inflammatory cells with increasing wound age. This may indicate an involvement of fibronectin in cell attraction and migration during wound healing. In 2 cases with a survival time of 17 days and in all cases more than 3 weeks old (group III; $n=8$ ) fibronectin was deposited as distinct short filaments in the connective tissue fibers and on the surface of fibroblasts in granulation tissue with decreasing staining intensity. Only in one case of a 28 -day-old extensive abrasion was a strong positive fibronectin staining observed in the region of the developing epithelium. This could be due to re-epithelialization which begins from epidermal areas of non-wounded skin and proceeds to the center of the wound area. Therefore immigration of epithelial cells apparently had not finished covering the wound surface.

The appearance of fibronectin associated with collagen fibrils in granulation tissue of skin lesions 18 days after wounding is in accordance with the reports of Grinnell et al. [13] in animals. Repesh and co-workers [31] described an intense fibronectin staining in 8-day-old granulation tissue in rabbits which could also be detected by us in granulation tissue of skin wounds with an age of less than 17 days, especially less than 3 weeks.

Our results indicate that extensive fibronectin networks develop with increasing wound age as well as en-



Fig. 5. Time-dependent appearance of fibronectin in the wound area of human skin lesions $(n=53)$. 1 : no positive fibronectin reaction; 2 : questionable fibronectin reaction; 3 : distinct positive fibronectin reaction; 4 : positive fibronectin reaction only in the granulation tissue

hanced cell migration into the wound area which can be detected by immunohistochemistry in skin lesions up to 3 weeks old. An earlier disappearance (at about 17 days) seems to be possible. After 3 weeks survival time it seems that fibronectin can only be observed on the surface of fibroblasts and between fibers of the granulation tissue (Fig. 5).

In summary, our results demonstrate that the immunohistochemical identification of fibronectin is useful for classifying skin lesions as vital and for differentiating between wounds less than 2 and more than 3 weeks old. Between the 2 nd and $3 \mathrm{rd}$ week after wounding the exact estimation of wound age does not seem possible on the basis of fibronectin distribution.

\section{References}

1. Alitalo $\mathrm{K}$, Hovi T, Vaheri A (1980) Fibronectin is produced by human macrophages. J Exp Med 147: 1779-1791

2. Berg S, Ditt J, Friedrich D, Bonte W (1968) Möglichkeiten der biochemischen Wundaltersbestimmung. Dtsch Z Gerichtl Med 63:183-198

3. Berg S, Elbel R (1969) Altersbestimmung subcutaner Blutungen. Muench Med Wochenschr 111:1185-1190

4. Berg S (1975) Vitale Reaktionen und Zeitschätzungen. In: Mueller B (eds) Gerichtliche Medizin, vol 1.Springer, Berlin Heidelberg New York, pp 326-340

5. Betz P, Penning R, Eisenmenger W (1991) Lipophagen der Haut als zusätzlicher Parameter für die histologische Wundalterschätzung. Rechtsmedizin 1:139-144

6. Boehm E, Tschomakov M (1973) Ein Sekundenphänomen der vitalen Reaktion. Beitr Gerichtl Med 31:221-229

7. Clark RAF, DellaPelle P, Manseau E, Lanigan JM, Dvorak HF, Colvin RB (1982) Blood vessel fibronectin increases in conjunction with endothelial cell proliferation and capillary ingrowth during wound healing. J Invest Dermatol 79:269-276

8. Clark RAF, Lanigan JM, DellaPelle P, Manseau E, Dvorak HF, Colvin RB (1982) Fibronectin and fibrin provide a provisional matrix for epidermal cell migration during wound reepithelialization. J Invest Dermatol 79:264-269

9. Davison P, Karasek M (1980) Serial cultivation of human dermal vessel endothelium: role of serum and fibronectin. Clin Res 28:566a

10. Eisenmenger W, Nerlich A, Glück G (1988) Die Bedeutung des Kollagens bei der Wundaltersbestimmung. Z Rechtsmed $100: 79-100$ 
11. Fechner G, Hernandez M, Bajanowski T, Sepulchre MA, Brinkmann B (1992) Immunohistochemical alterations after muscle trauma. Int J Leg Med (in press)

12. Grinnell F, Feld M, Minter D (1980) Fibroblast adhesion to fibrinogen and fibrin substrata: requirement for cold-insoluble globulin (plasma fibronectin) Cell 19:517-525

13. Grinnell F, Billingham RE, Burgess L (1981) Distribution of fibronectin during wound healing in vivo. $\mathbf{J}$ Invest Dermatol 76:181-189

14. Hörmann H, Seidl M (1980) Affinity chromatography on immobilized fibrin monomer, III. The fibrin affinity center of fibronectin. Hoppe Seylers Z Physiol Chem 361:1449-1452

15. Hörmann H (1982) Fibronectin-mediator between cells and connective tissue. Klin Wochenschr 60:1265-1277

16. Hsu SM, Raine L, Fanger HC (1981) A comparative study of the peroxidase-antiperoxidase method and an avidin-biotin complex method for studying polypeptide hormones with radio immunoassay antibodies. Am J Clin Pathol 75:734-739

17. Jaffee EA, Mosher DF (1978) Synthesis of fibronectin by cultured human endothelial cells. J Exp Med 147:1779-1791

18. Jarecki R, Arndt U, Schultz C, Klein H (1969) Zur Unterscheidung vitaler und postmortaler Wunden durch Bestimmung des Esterasemusters der Haut. Dtsch Z Ges Gerichtl Med 66:161-169

19. Jilek F, Hörmann H (1979) Fibronectin (cold insoluble globulin), VI. Influence of heparin and hyaluronic acid on the binding of native collagen. Hoppe Seylers Z Physiol Chem 360: $597-603$

20. Kurkinen M, Vaheri A, Roberts PJ, Steinman S (1980) Sequential appearance of fibronectin and collagen in experimental granulation tissue. Lab Invest $43: 47-57$

21. Linder E, Stenman S, Lehto V-P, Vaheri A (1978) Distribution of fibronectin in human tissues and relationship to other connective tissue components. Ann NY Acad Sci 312:151-159

22. Mosher DF (1975) Cross linking of cold insoluble globulin by fibrin stabilizing factor. J Biol Chem 250:6614-6621

23. Mosesson MW, Umfleet RA (1970) The cold-insoluble globulin of human plasma. I. Purification, primary characterization, and relationship to fibrinogen and other cold-insoluble fraction components. J Biol Chem 245:5728-5736

24. Nerlich A, Berndt R, Schleicher E (1991) Differential basement membrane composition in multiple epitheloid haeman- gioendotheliomas of liver and lung. Histopathology 18:303307

25. Niewiarowski St, Regoezi E, Mustard JF (1972) Adhesion of fibroblasts to polymerizing fibrin and retraction of fibrin induced by fibroblasts. Proc Soc Exp Biol Med 140:199-204

26. Oehmichen M, Schmidt V, Stuka K (1989) Freisetzung von Proteinase-Inhibitoren als vitale Reaktion im frühen posttraumatischen Intervall. Z Rechtsmed 102:461-472

27. Oehmichen M (1990) Die Wundheilung. Springer, Berlin Heidelberg New York

28. Postlethwaite AE, Keshi-Oja J, Balian G, Kang AH (1981) Induction of fibroblast chemotaxis by fibronectin. J Exp Med $153: 494-499$

29. Raekallio J (1965) Die Altersbestimmung mechanisch bedingter Hautwunden mit enzymhistochemischen Methoden. Schmidt Römhild, Lübeck

30. Raekallio J (1972) Determination of the age of wounds by histochemical and biochemical methods. Forensic Sci 1:3-6

31. Repesh LA, Fitzgerald TJ, Furcht LT (1982) Fibronectin involvement in granulation tissue and wound healing in rabbits. J Histochem Cytochem 30:351-358

32. Ruoslahti E, Vaheri A (1974) Novel human serum protein from fibroblast plasma membrane. Nature 248:789-791

33. Ruoslahti E, Vaheri A (1975) Interaction of soluble fibroblast surface antigen with fibrinogen and fibrin. Identity with coldinsoluble globulin of human plasma. J Exp Med 141:497-501

34. Schneider V (1974) Über rasterelektronenmikroskopische Untersuchungen an vital und postmortal entstandenen "Thromben". Z Rechtsmed 74:47-54

35. Stenman S, Vaheri A (1978) Distribution of a major connective tissue protein, fibronectin, in normal human tissues. J Exp Med 147: 1054-1064

36. Vaheri A, Ruoslahti R, Westermark B, Pontén J (1976) A common cell type specific surface antigen in cultured human glial cells and fibroblasts: loss in malignant cells. J Exp Med $143: 64-72$

37. Viljanto J, Penttinen R, Raekallio J (1981) Fibronectin in early phases of wound healing in children. Acta Chir Scand 147: 7-13

38. Yamada KM, Olden K (1978) Fibronectins: Adhesive glycoproteins of cell surface and blood. Nature $275: 179-184$ 